\title{
Tentative world-wide correlation of Early Cretaceous strata by limestone-marl cyclicities in pelagic deposits
}

\author{
PIERRE COTILLON
}

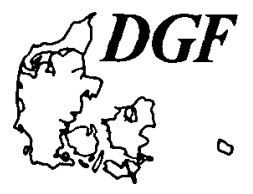

\begin{abstract}
Cotillon, P.: Tentative world-wide correlation of Early Cretaceous strata by limestone-marl cyclicities in pelagic deposits. Bull. geol. Soc. Denmark, vol. 33, pp. 91-102, Copenhagen, September, 11th, 1984. https://doi.org/10.37570/bgsd-1984-33-07

Bed-scale pelagic marl-limestone alternations at a number of localities in the Tethyan realm are cyclic and display common characters related to duration, composition, mineralogical and microfaunal content. Parameters used to characterize the cycles show parallel evolutions in time over large areas and thus allow accurate correlation. Cycle thickness variations, figured by "cyclograms", makes it possible to correlate sequences from southeastern France to the northeastern Gulf of Mexico and also to apply the biozonation of Angles' parastratotype, located in the Vocontian Trough, to the oceanic Valanginian sections. Variation curves of minor cycle frequency also expresse the accumulation rate which is mainly influenced by the production of planktonic carbonate. They allow North Atlantic and worldwide correlations, particularly for Hauterivian and Albian sections. Whatever the global cause was controlling the variation of planktonic productivity (either very long-term climatic fluctuations or eustatic changes), the curves, which reflect these variations, present an efficient stratigraphic tool for transoceanic correlations especially when biostratigraphic methods are ineffective. Furthermore, they reflect some major Lower Cretaceous boun-daries of the western Tethys.
\end{abstract}

Pierre Cotillon, Departement des Sciences de la Terre et Laboratoire associté au CNRS no 11, 24-43 Bd du 11 Novembre, 69622 Villeurbanne Cedex. May 3rd, 1984.

\section{Introduction}

For a number of years, studies of bed-scale cyclicity pelagic deposits have been undertaken to characterize the so-called "limestone-marl alternations", in order to determine a link between this layering and long-term climatic fluctuations. Quaternary and Tertiary successions yielded the first results (Arrhenius 1952, Hays et al. 1976, Pisias 1976, Briskin and Harrel 1980, Kerr 1981, Dean et al. 1981, Moore et al. 1982). Indeed, some of these series recorded climatic fluctuations which, although disturbed, were enhanced by the glacial events (Moore et al. 1982, Kerr 1981). More recently, Cretaceous and even Paleozoic sections have been investigated (Arthur 1979, McCave 1979, Cotillon et al. 1980, Michel 1981, Ferry and Schaff 1981, De Boer 1982,Schwarzacher and Fischer 1982, Kauffman 1982). The aim of this study has been to gain a better knowledge of the main possible causes of the cyclicity in pelagic Lower Cretaceous sequences and at the same time to use the cyclicity as a tentative stratigraphic tool, thus allowing accurate correlations over widespread areas.
Analyzed successions (fig. 1)

The setting for the first studies were Tethyan margins principally in the Vocontian Trough, located in the Subalpine Ranges of southeastern France. In this basin, we verified the striking continuity shown by the beds and interbeds of a Valanginian mark-section (Le Toulourenc succession) across the entire basin over $10,000 \mathrm{~km}^{2}$ (Cotillon et al. 1980). Furthermore, we thoroughly examined the cyclicity of a Neocomian section at Angles and Vergons, located in the eastern part of the basin. (Cotillon and Rio, in press).

Along southern Tethyan margins, we focused our attention on two areas: - the Lombardian basin (northern Italy) where the Lower Cretaceous deposits are thinner and much more calcareous (Majolica facies) than in southeastern France. - Northeastern Tunisia, and more precisely the Djebel Oust basin, where sections are expanded due to detrital input.

Finally, we studied limestone-marl cycles at 


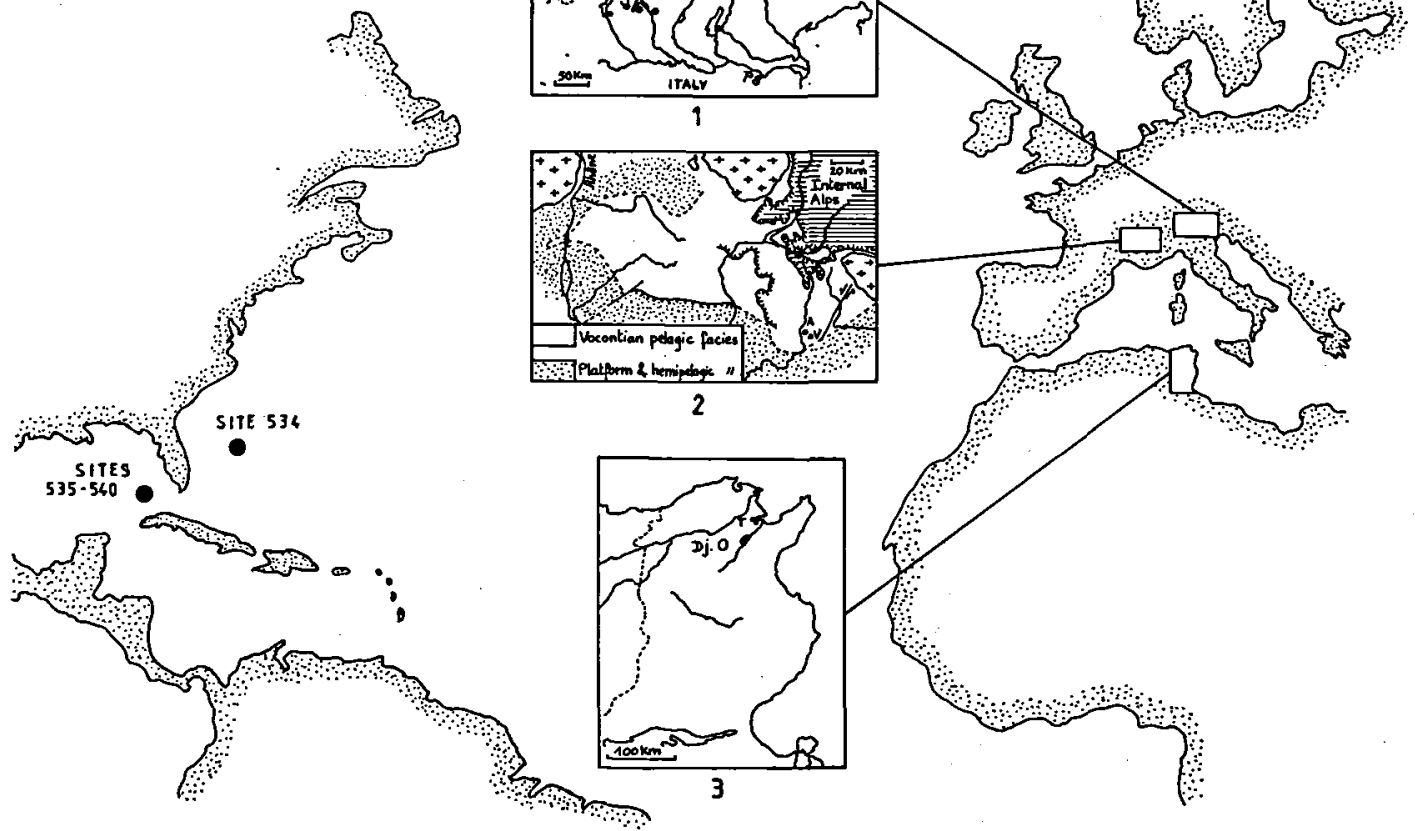

Fig. 1. Location of areas investigated for Lower Cretaceous bedscale cyclicity.

1: Lombarian Alps, 2: Vocontian Trough, in southeastern France (Subalpine Ranges). A: Angles, V: Vergons, 3: northeastern Tunisia, DJO: Djebel Oust Basin.

several oceanic sites (Cotillon and Rio, in press). For some (DSDP site 534, Central Atlantic, sites 535 and 540 in southeastern Gulf of Mexico) our investigations were based on samples and core photographs. For others (DSDP sites 370, 386, 387, 398 in North Atlantic, 369 and 364 in South Atlantic, 167 in Mid Pacific) we only used core photographs.

\section{Characters and significance of analyzed cycles}

The investigated sections consist of bed-scale sequences comprising two or three of the following lithological units:

Clear micritic limestone which contains more than $80 \% \mathrm{CaCO}_{3}$ and occurs as hard beds generally burrowed throughout. The maximum development of planktonic remains occurs in these beds, in particular, nannoconids which constitute the bulk of the micrite. Radiolarians calcitized during the diagenesis also occur.

Grey marly limestone, with 60 to $80 \% \mathrm{CaCO}_{3}$. These beds show a maximum diversity of planktonics including foraminifera and radiolarians (Darmedru et al. 1982).

Dark marl or black shale interbeds in which $\mathrm{CaCO}_{3}$ content reaches at maximum $60 \%$. Marls are the richest both in benthonic remains and coccoliths. These beds correspond to the least diversified and dense microfaunal populations.

Marls and marly limestones, which are rarely bioturbated at oceanic sites, are generally laminated.

In all the areas mentioned the bed-scale cycles show approximately the same range of duration. According to stratigraphic stages at Angles-Vergons and at sites 534, 535, 540, they vary from 3000 to 72,000 years and average between 10,000 and 26,000 years for major cycles and between 4000 and 11,000 years for minor cycles. These values are consistent with other estimations related to the same type of cycles (table 1).

We also observed a similar distribution of the chief sediment components forming the cycles. For example:

Limestone like clay follows a sinusoidal varia- 


\begin{tabular}{|c|c|c|c|}
\hline LOCATION & AGE & DURATION OF CYCLES & AUTHORS \\
\hline $\begin{array}{l}\text { Site } 367 \text { (Cape } \\
\text { Verde Basin) }\end{array}$ & $\begin{array}{l}\text { Early Cretaceous } \\
\text { Core } 26\end{array}$ & 37,000 years & DEAN et al., 1978 \\
\hline $\begin{array}{l}\text { Site } 463 \text { (mid } \\
\text { Pacific Mountains }\end{array}$ & $\begin{array}{l}\text { Upper Aptian to } \\
\text { Early Albian }\end{array}$ & $\begin{array}{r}14,000 \text { to } 38,000 \\
\text { years }\end{array}$ & FERRY et al., 1981 \\
\hline $\begin{array}{l}\text { Sites } 386 \text { and } 387 \\
\text { (Western North } \\
\text { Atlantic) }\end{array}$ & Albian & $\begin{array}{r}17,000 \text { and } 20,000 \\
\text { years }\end{array}$ & MCCAVE, 1979 \\
\hline $\begin{array}{c}\text { Sites } 399 \text { and } 400 \\
\text { (Bay of Biscay) } \\
\text { " }\end{array}$ & $\begin{array}{l}\text { Albian } \\
\text { Aptian }\end{array}$ & $\begin{array}{r}36,000 \text { to } 44,000 \\
\text { years } \\
21,000 \text { to } 29,000 \\
\text { years }\end{array}$ & $\begin{array}{c}\text { MONTADERT et al. } \\
1979 \\
\text { " }\end{array}$ \\
\hline $\begin{array}{l}\text { Site } 398 \text { (North } \\
\text { Atlantic) }\end{array}$ & Aptian-Albian & 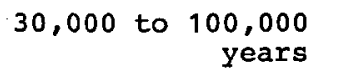 & ARTHUR, 1979 \\
\hline $\begin{array}{l}\text { Western Interior } \\
\text { U.S.A. }\end{array}$ & Cretaceous & $\begin{array}{r}30,000 \text { to } 50,000 \\
\text { years }\end{array}$ & KAUFFMAN, 1982 \\
\hline Umbria (Italy) & Mid Cretaceous & 23,400 years & De BOER, 1982 \\
\hline
\end{tabular}

Table 1. Some examples of limestone-marl cycle duration in pelagic Early and Middle Cretaceous sediments.

tion of concentration that is inconsistent with the distribution of the same materials within turbidites (Cotillon et al. 1980).

Organic matter is always more abundant in marls than in limestones (cf. Lancelot et al. 1972, Thierstein 1979, Arthur 1979, Melières et al. 1981, Brumsack and Lew 1982).

The microfaunal distribution parallels, or is opposite, to the lithological cyclicity expressed by calcimetric curves (Darmedru et al. 1982).

These characters lead to a common interpretation for all the studied bed-interbed cycles. That is an alternation between periods of high planktonic production in ventilated environments (for the limestones) and periods of both weak photic layer fertility and bottom stagnant conditions (for the marls) (Cotillon and Rio, in press).

Only global controls may explain the common characters and the extensive distribution of alternating series. The most likely is climatic events, which were invoked many years ago, and are often thought to be induced by variations of
Earth orbital parameters which follow three periods; 21,000, 41,000 and 100,000 years (Croll 1864, Milankovitch 1930, 1941, Imbrie 1982).

This climatic hypothesis is strengthened by the trans- and interoceanic correlations based on limestone-marl cyclicity.

\section{Cyclicity correlations}

These correlations are based on the variation through time of some parameters characterizing bed-interbed cycles:

The thickness, measured between the base of two successive marly interbeds (fig. 2), is used, with other criteria, to distinguish two kinds of cycles: major cycles, over $10 \mathrm{~cm}$ thick, displaying a great amplitude of calcimetric variation; minor cycles, over $5 \mathrm{~cm}$ thick, which occur within the major cycles and show weak calcimetric variations.

The frequency, which is the number of cycles occurring within given intervals, e.g. the drilling cores of the Deep Sea Drilling Project $(9.5 \mathrm{~m})$. 


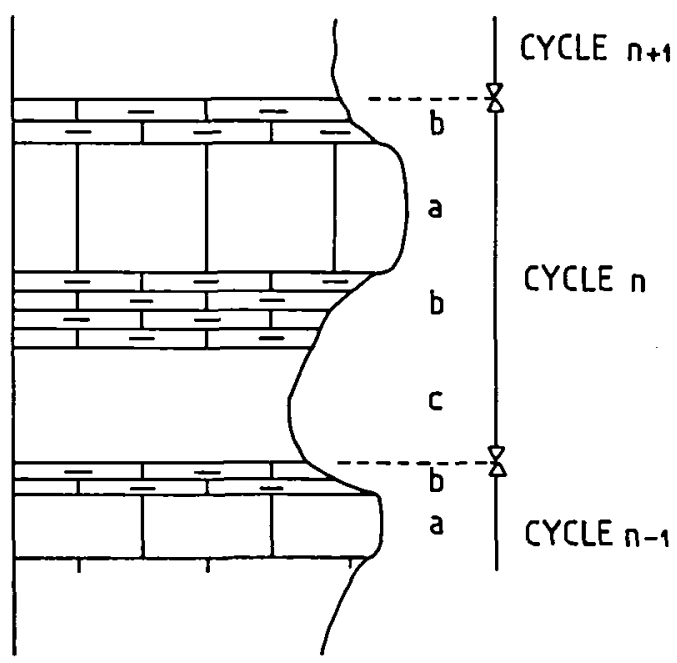

Fig. 2. Conventions for cycle characterization: a: limestone unit, b: marly limestone unit, c: marly unit.

Western Tethys correlations using cycle-thickness variation

(fig. 3).

For three sites: 534, 535 and Angles-Vergons (Vocontian basin), "cyclograms" were constructed showing the thickness variation of major cycles through the Valanginian-Hauterivian succession. This sequence was approximately delimited and subdivided offshore by available biostratigraphic markers.

The main elements used for the correlations are the following:

- general evolution of the thickness of bedinterbed cycles which is megacyclic by itself.

- discontinuities of this evolution.

- particular groups of cycles, for instance, cycles with a similar length which follow each other.

- proportions and distribution of long cycles with regard to short ones. Based on these criteria, plus the biostratigraphic markers, close similarities appear at many points on the cyclograms. They allow accurate correlation of the three successions and to use for Valanginian oceanic series the biozonation of Angles' parastratotype.

Besides, this correlation evidences a gap of the uppermost Hauterivian section at site 535.

\section{Worldwide correlations using cycles-} frequency variation

The curves of major cycle frequency for Valanginian-Hauterivian successions at sites 535, 534 and Angles-Vergons (fig. 4), show similar evolution until the upper Valanginian (Trinodosum zone of the Angles-Vergons succession) and for the whole Neocomian in the two DSDP sites. In addition, particular points appear at the same levels in the three sites - situated at changes in evolutionary trends. One (A) occurs at the lower/upper Valanginian transition and the other (B) just above the Valanginian - Hauterivian transition (1). As with the cyclograms, the curves of the major cycle frequency display a gap at the uppermost Hauterivian section at site 535 .

Other curves (fig. 5), drawn for the Cenomanian (?) at site 535 and the Albian at site 540, 20 $\mathrm{km}$ apart, demonstrates partial overlapping (parts X Y Z of the curves).

Such a result aboard the Glomar Challenger on Leg 77 could not have been achieved by the traditional methods of correlation based on lithology and biostratigraphy.

The curves of minor cycles frequency were also utilised. At two Neocomian sites (534 and 391) (fig. 6), $40 \mathrm{~km}$ apart in the same basin, some stratigraphical boundaries are evident in a succession (at site 391) which was hitherto inadequately subdivided.

Similar curves (fig. 7) have been drawn for the Neocomian of sites 534 and 535, which occur in two different basins $1100 \mathrm{~km}$ apart separated by the Bahamian Platform. Several points of correlation $(\mathrm{C}$ to $\mathrm{H})$ are evident. The gap of the uppermost Hauterivian section at site 535 again appears when the curves are compared.

Finally, the similarity between curves of the Hauterivian and Albian sections of 8 Atlantic and one Pacific sites suggests possibilities for worldwide correlation (fig. 8-9).

\section{Discussion}

The parallel evolution through time of parameters used for characterization of bed-interbed cyclicity confirms the hypothesis of global control of alternating sedimentation.

Climatic fluctuations most likely explain the 


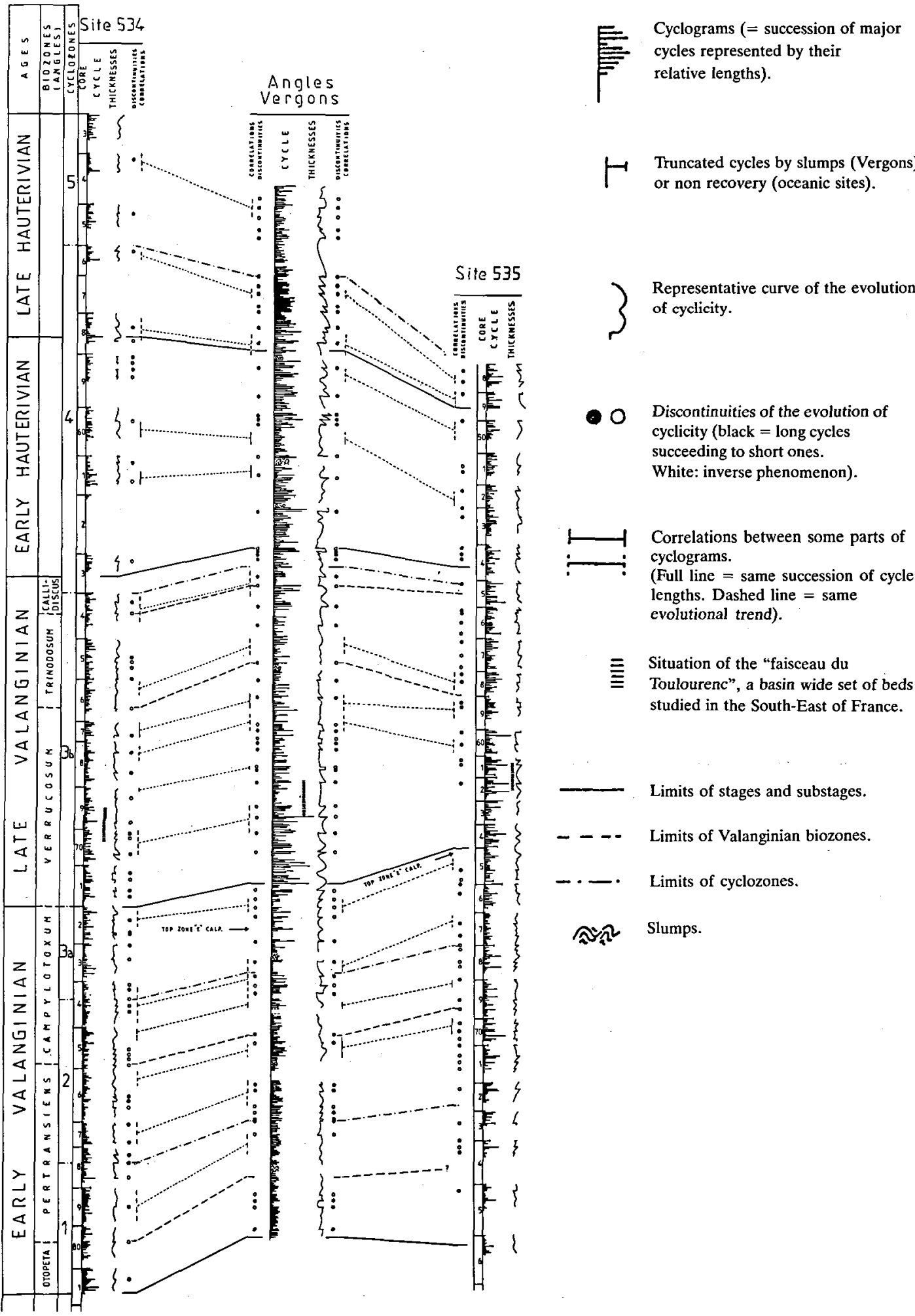

Fig. 3. Correlations between Sites 535, 534 and Angles-Vergons, based on the cyclicity of deposits illustrated by "cyclograms" (for Valanginian and Hauterivian periods only). 


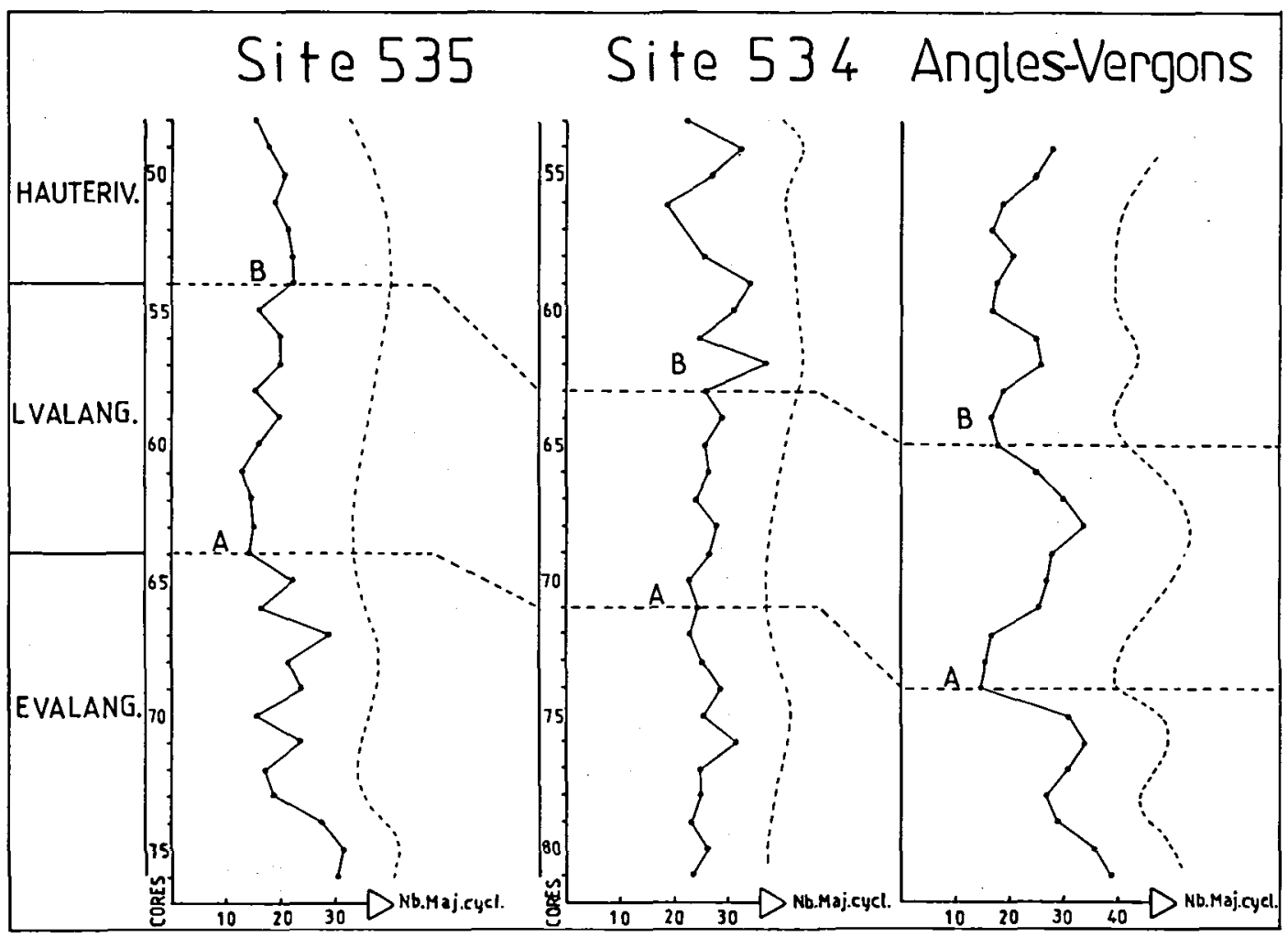

Fig. 4. Evolution of the number of major cycles per core or per $15 \mathrm{~m}$ of deposit (Angles-Vergons) across the Valanginian-Hauterivian interval.

$\mathrm{A}$ and $\mathrm{B}$ are two correlated trend reversals. Stratigraphic boundaries are represented by dashed lines.

decimetric limestone-marl cyclicity. The most frequent periods for major cycles fall into four groups: 11,500 to $15,000,18,000$ to 22,000 , 25,000 to 28,000 and 35,000 to 39,000 years. The most frequent megacycles displayed by the cyclograms are $48,000,64,000,80,000$ and 96,000 years long. These numbers are consistent with many other estimates for alternating series (Fischer 1980, Dean et al. 1981, De Boer 1982, Schwarzacher and Fischer 1982) for which dependence on Milankovitch cycles is invoked.

The more ore less cyclic fluctuations followed by the curves of minor cycle frequency may be related to accumulation rate variations. In different stratigraphical units of Early Cretaceous age at sites 534,535 and 540 , the average frequency of minor cycles per core correlates with the accumulation rate calculated according to the time scale proposed by Kennedy and Odin (1982) (Cotillon 1983) (fig. 10).

Theoretically, in the studied successions two factors may govern the accumulation rate: the calcareous production of near-surface water and the dissolution of calcareous particles during deposition.

The reality of the first factor is proved by the following observations:

- the bulk of micrite in both limestone and marly beds results from accumulation of nannoconids and coccoliths.

- the mean thickness of limestone beds is nearly twice that of marly interbeds, and the former have accumulated more quickly than the latter (Cotillon, Gaillard and Jautée under study).

- at sites 535 and 540 the bulk of ${ }^{13} \mathrm{C}$ in sediments, generally considered to reflect planktonic productivity, is positively correlated to accumulation rate (fig. 11).

The second factor (dissolution) appears unlikely because there is no significant evidence that it occurred on the calcareous biological re- 


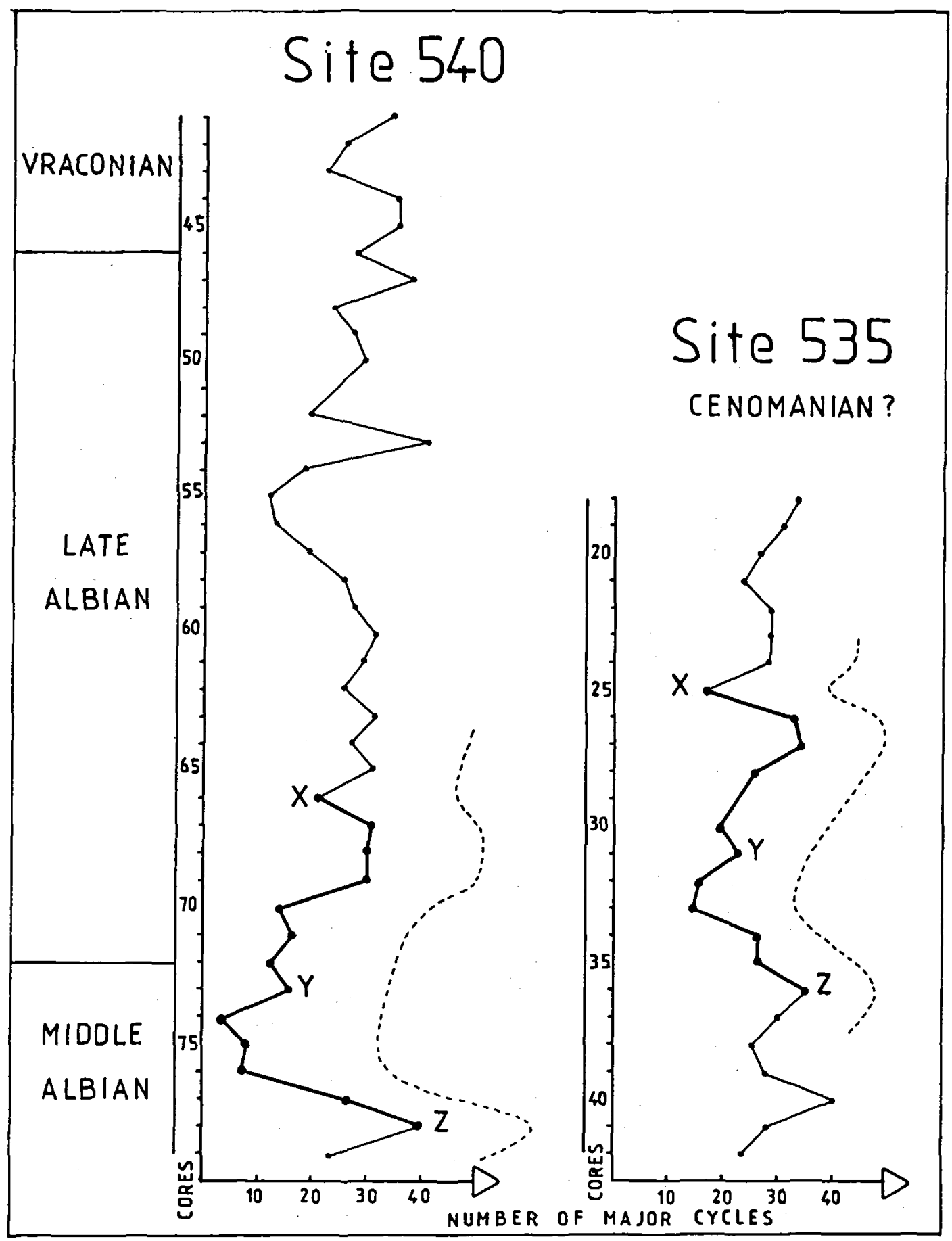

Fig. 5. Evolution of the number of major cycles per core (Albian at Site 540, Cenomanian (?) at Site 535). X, Y, Z: possible correlated points. 


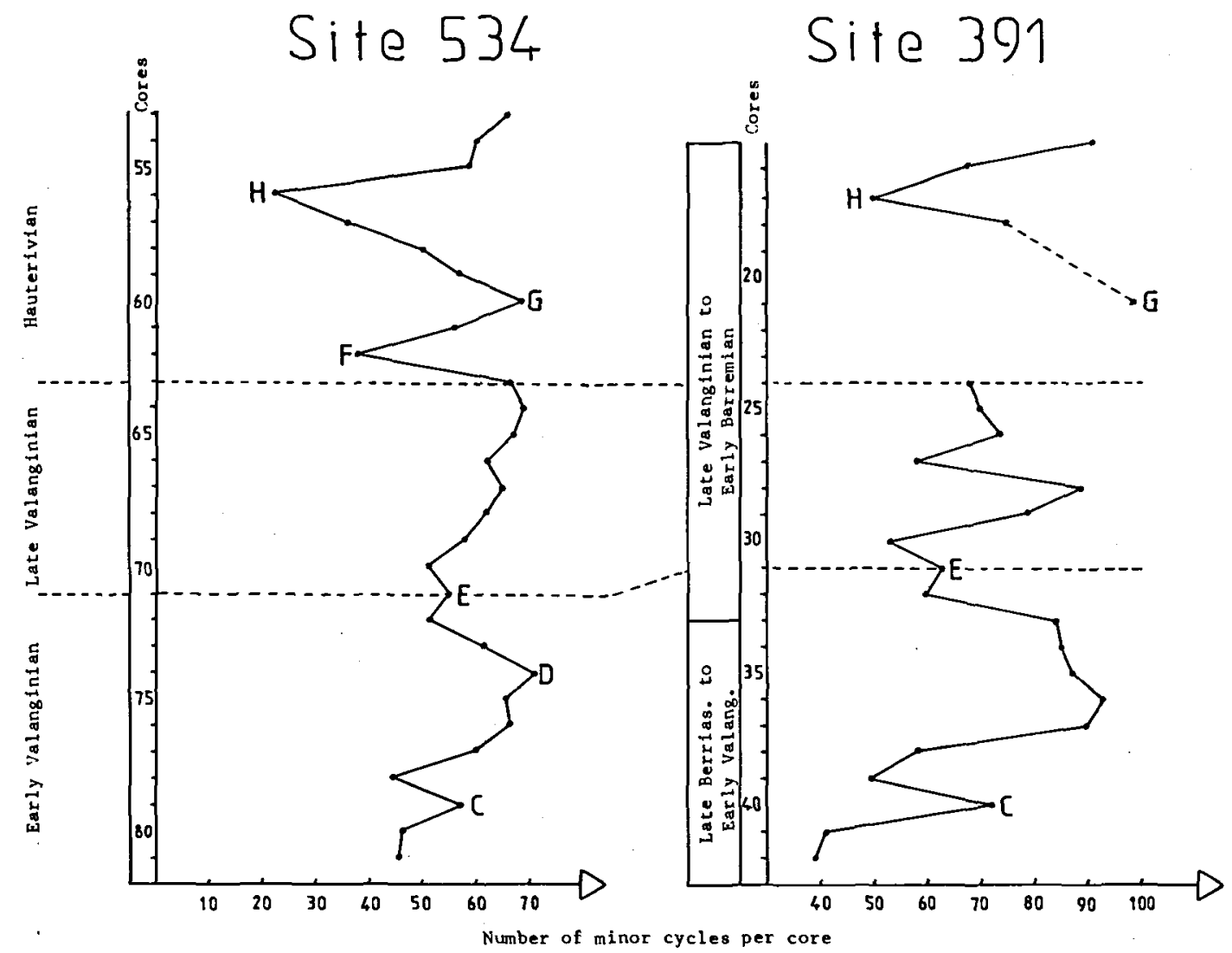

Fig. 6. Evolution of the number of minor cycles per core across the Valanginian-Hauterivian interval at Sites 534 and $391, \mathrm{C}$ to $\mathrm{H}$ : correlated points of the minor cycles curves. Stratigraphic boundaries are represented by dashed lines.

mains. Furthermore, all these sediments have settled above the CCD.

There are two main possibilities often associated which may influence the near-surface water fertility of the world-ocean. These include longterm climatic fluctuations running to one million years or eustatic variations. In each case, the environment (through oxygenation, temperature, currents, nutrient concentration) and terrestrial supplies may be affected and consequently the planktonic production.

According to Arthur (1979), Vincent (1981), Berger (1982) and De Boer (1982), the fluctuation of sea level moves the terrestrial source of suspended, dissolved, mineral and organic products away or towards the basin center. This modifies the current circulation and consequently may favour or reduce the planktonic activity.

Climate and eustatic sea-level changes may also determine the CCD position (Berger and Winterer 1974, Denis Clochiatti 1982).

Whatever their actual significance, the cycle frequency variation curves represent an efficient stratigraphic tool, facilitating transoceanic correlations, especially when biostratigraphic methods are ineffective. Furthermore, significant trend reversals reflect some major western Tethyan Lower Cretaceous boundaries. Example of this include the boundaries between the Early and Late Valanginian and between the Valanginian and Hauterivian successions (figs. 4, 7). The first of these boundaries is particularly important because it relates to the following concomitant events:

- a lithological break in southeastern France, eventually accompanied by a stratigraphical gap (Arnaud et al. 1981). 


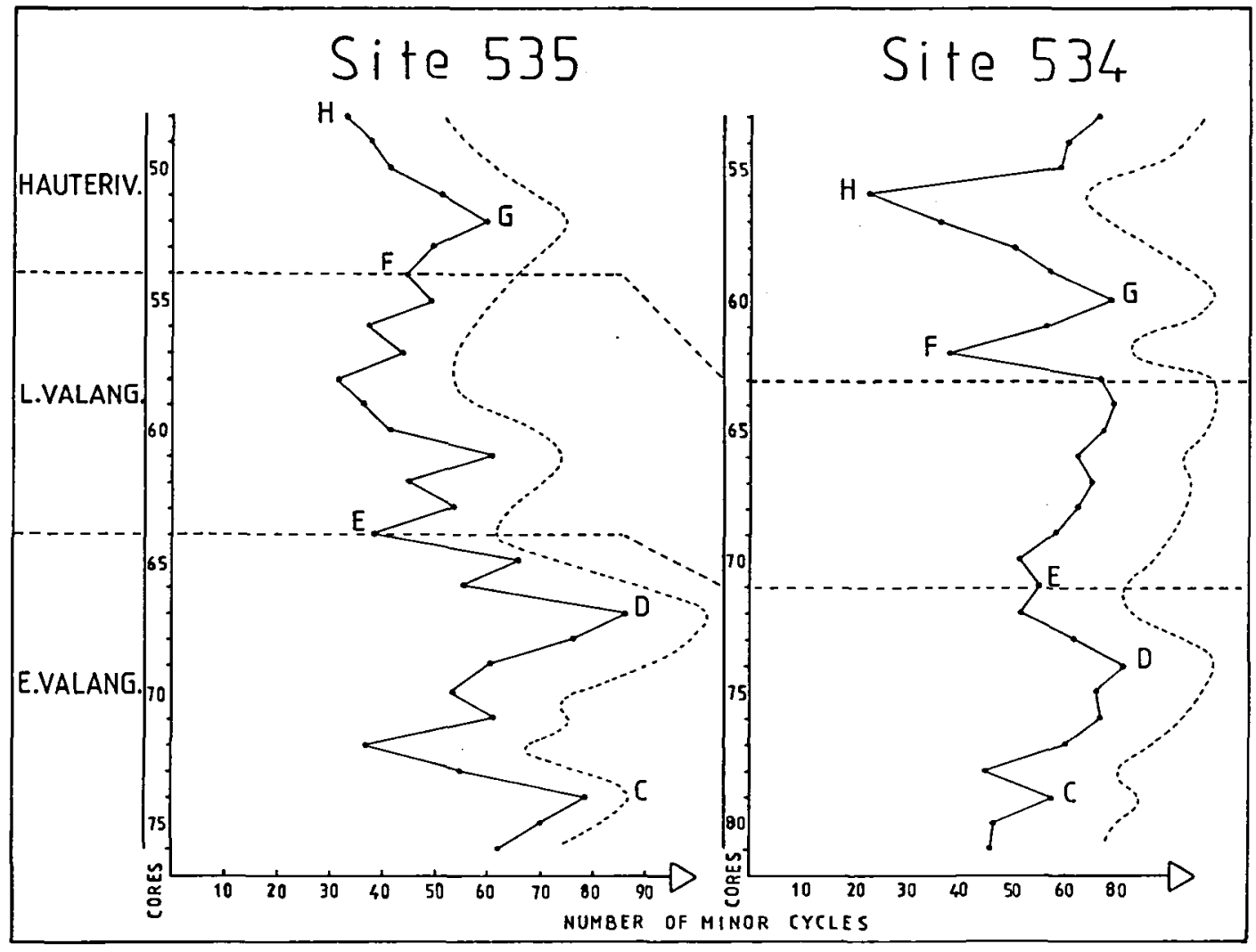

Fig. 7. Evolution of the number of minor cycles per core across the Valanginian-Hauterivian interval at Site 535 and 534 (full and dashed lines). $\mathrm{C}$ to $\mathrm{H}$ : correlated points of the minor cycles curves. Stratigraphic boundaries are represented by dashed lines.

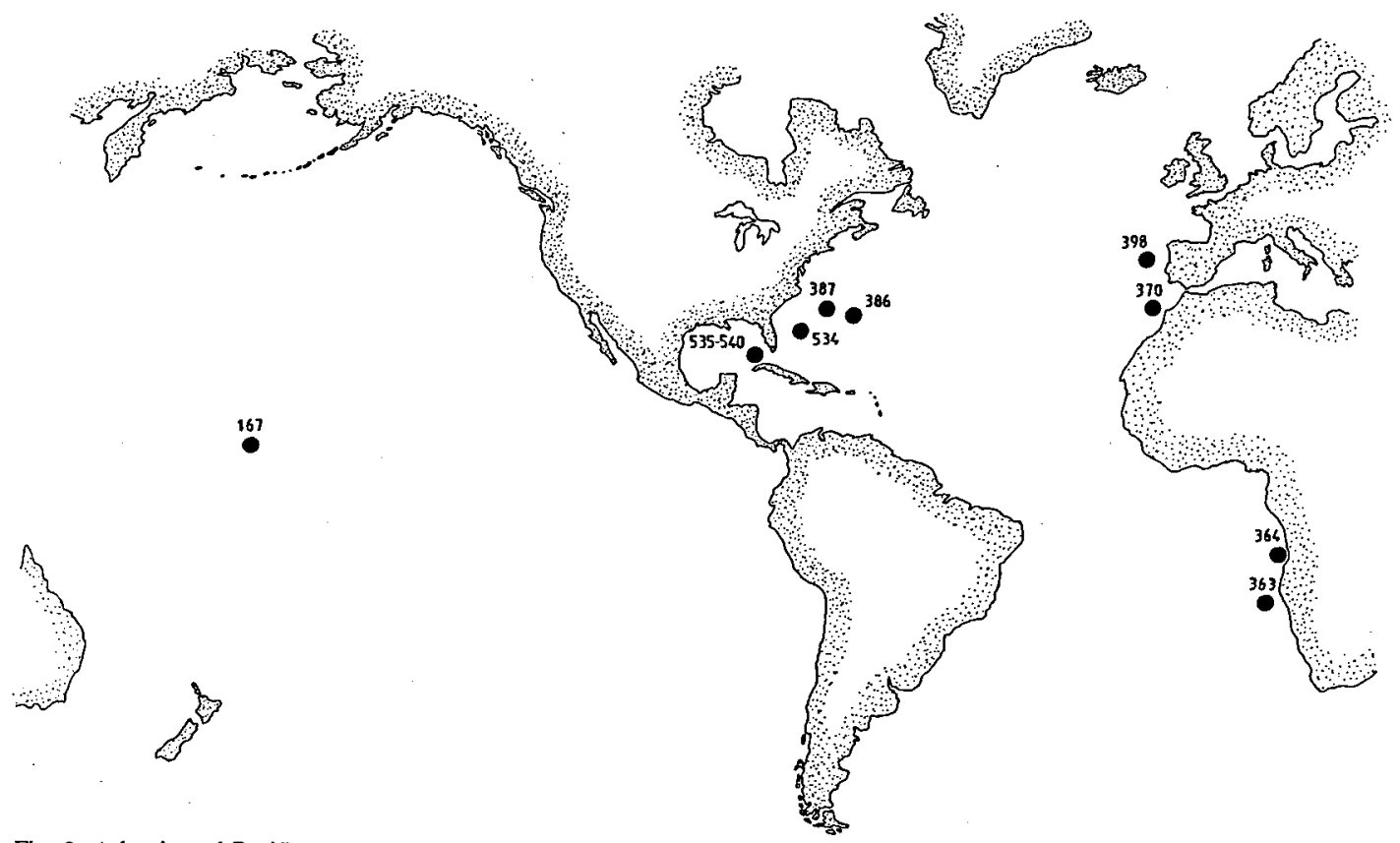

Fig. 8. Atlantic and Pacific DSDP sites where Hauterivian and Albian sections may be correlated through curves of minor cycle frequency. 

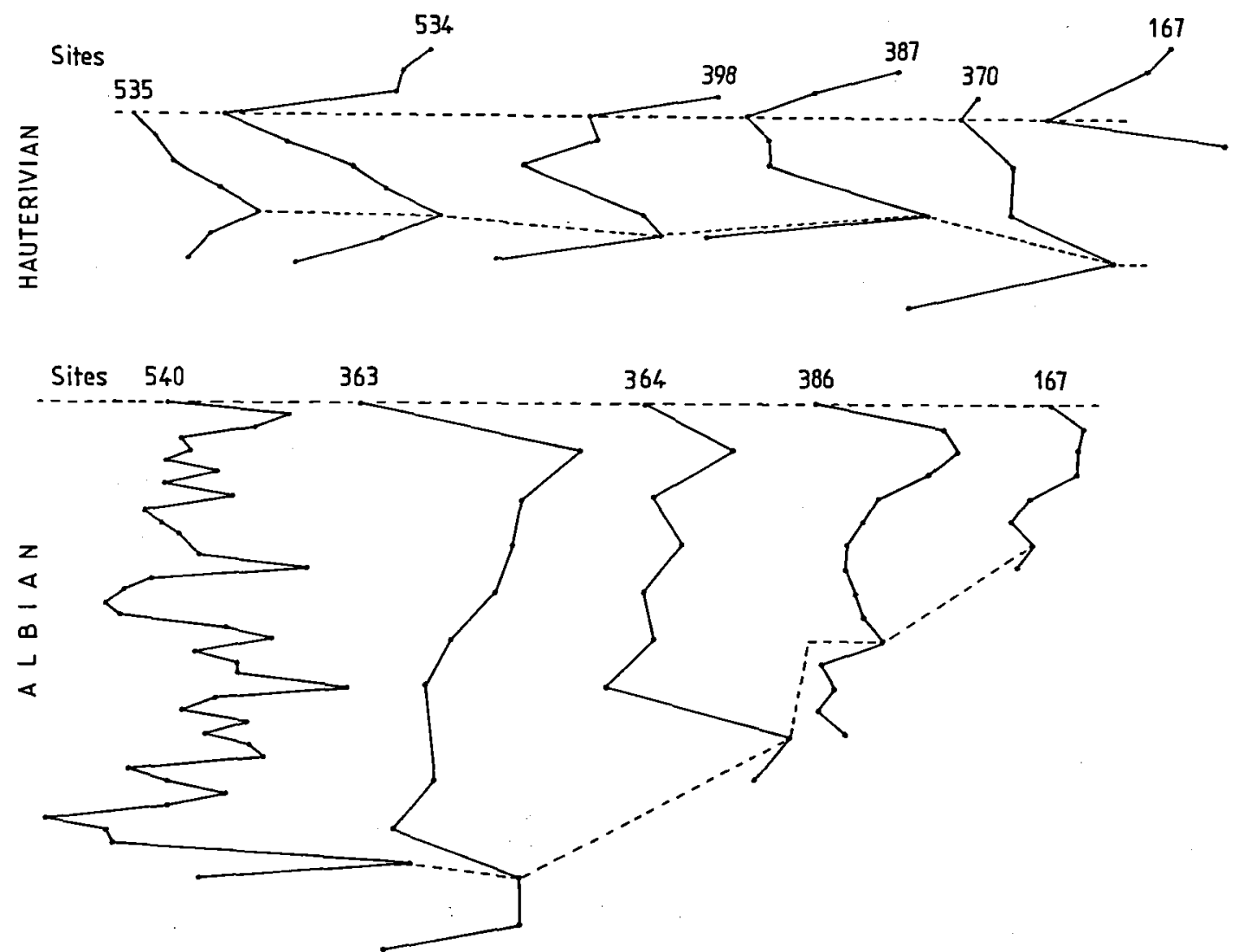

Fig. 9. Curves of minor cycle frequency drawn for Hauterivian and Albian sections of the Atlantic and Pacific DSDP sites. Dashed lines: correlated levels.

- in the Vocontian basin a greater supply of silt accompanying clay minerals.

- geochemical signals pointed out in the Gulf of Mexico (Debrabant $e t$ al. in press) and at site 534 (Chamley et al. 1983).

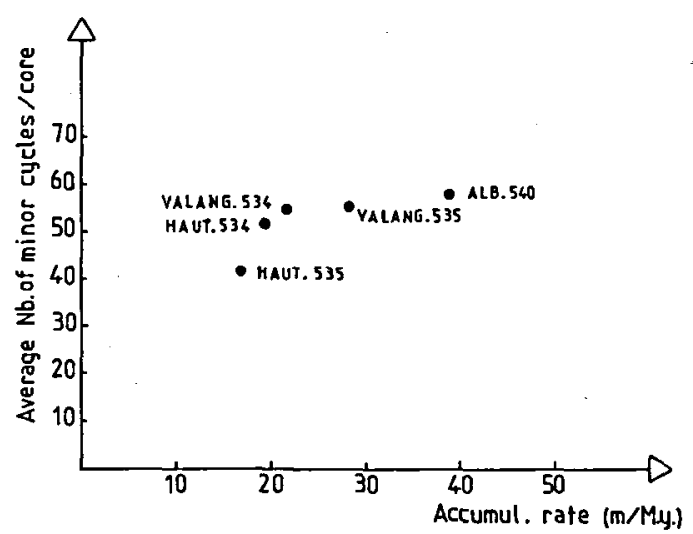

Fig. 10. Correlation between the average number of minor cycles per core, calculated for some stratigraphic intervals, and the sedimentation rate.
- in the Vocontian realm a faunal renewal (Boisseau et al. 1982).

- an invasion of boreal ammonites into the Tethys (Thieuloy 1977).

Unfortunately, the correlation method by cyclograms and by the curves of minor cycle fre-

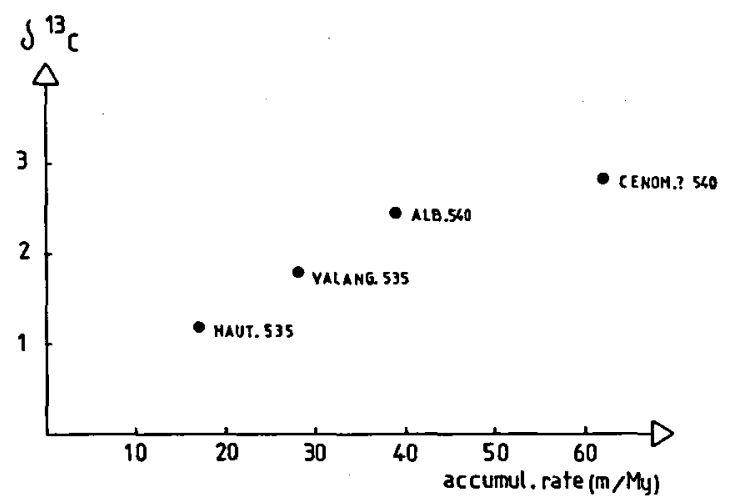

Fig. 11. Average $\delta 13 \mathrm{C}$ for several stratigraphic intervals of Sites 535 and 540 successions versus rates of sedimentation. 
quency are inappropriate when drilled sediments are poor recovered, when accumulation rates are vastly different or when lateral supplies of sediment are important.

\section{Conclusions}

The proposed correlation between offshore and onshore successions, on the basis of limestonemarl cyclicity, confirm that the alternation and its characters (frequency and thickness of bed-interbeds couplets) was controlled by global causes. Climatic variations, linked possibly to Earth orbital fluctuations (Milankovitch's cycles) could explain the bed-scale cycles and the evolution of their thickness in time.

Greater-order climatic or eustatic variations would have induced the evolution through time of cycle frequency which, in the case of minor cycles, parallels the evolution of calcareous planktonic productivity.

Cyclograms and curves expressing these variations appear as useful stratigraphic tools which may compensate for a lack of biostratigraphic data and improve the correlation of pelagic sections over widespread areas.

These correlations have confirmed the importance of some Neocomian stratigraphic boundaries, which reflect global events.

\section{Dansk sammendrag}

Pelagiske kalk- og mergel sekvenser fra nedre kridt i Tethysområdet er cykliske. Parametre brugt til karakterisering af cyklerne (mægtighed, sammensætning, mineralogiske og mikropalæontologiske data) viser parallel udvikling i tid over store områder og cyklerne kan således benyttes til nøjagtig korrelation. Konstruktion af "cyklogrammer «, baseret pả variation $i$ mægtighed tillader således korrelation af sekvenser fra det sydøstlige Frankrig til den mexicanske golf $\mathrm{i}$ valanginien. Variationer $i$ det cykliske mønster, der afspejler den globale planktonproduktion, kan, specielt i hauterivien og albien, bruges til transoceanisk korrelation.

\section{References}

Arnaud, H., Gidon, M., Thieuloy, J. P., 1981: Les calcaires du Fontanil des environs de Grenoble: leur place dans la stratigraphie du Néocomien entre le Jura et le domaine vocantien. Eclogae Geol. Helv. 74/1, 109-137.

Arthur, M. A., 1979: North Atlantic Cretaceous black shales: the record at site 398 and a brief comparison with other occurrences. In Sibuet J. C., Ryan W. B. F. et al., Init. Repts. DSDP, 42: Washington (U.S. Govt. Printing Office), $719-751$.

Arrhenius, G., 1952: Sediment cores from the East Pacific; Rept. Swedish Deep Sea Exped. (1947-1948) 5, 1-128.

Berger, W. H., 1982: Deep-Sea stratigraphy: Cenozoic climate steps and the search for chemo-climatic feedback. In: Cyclic and Event Stratification, Einsele G. and Seilacher A. (eds.), Spring. Verl., 456-475.

Berger, W. H. and Winterer, E. L., 1974: Plate stratigraphy and the fluctuating carbonate line, in Pelagic sediments on land and under the sea. Hsï, K. J. and Jenkyns, H. C. (eds.), Internat. Assoc. Sedimentologists spec., publ. 1, $59-96$.

Boer De, P. L., 1982: Cyclicity and the storage of organic matter in Middle Cretaceous Pelagic sediments. In: Cyclic and Event stratification, Einsele, G., and Seilacher, A., (eds.), Spring. Verl., 456-475.

Boisseau, T., Thieuloy, J. P., Arnaud-Vanneau, A., and Arnaud, H., 1982: Crises biologiques, coupures biostratigraphiques et migrations de faunes: l'exemple du Valangien dans le Sud-Est de la France. 9e réunion annuelle des Sciences de la Terre, Paris, Soc. géol. Fr. (ed.), 64. (abstract of comm.).

Briskin, M. and Harrell, J., 1980: Time series analysis of the Pleistocene deep-sea paleoclimatic record. Marine Geol. 36 , no 1-2, 1-22.

Chamley, H., Debrabant, P., Candillier, A. M. \& Foulon, J., 1983: Clay mineralogical and inorganic geochemical stratigraphy of Blake Bahama basin since the Callovian (Site 76, leg 76DSDP). Init. Repts. DSDP, 76: Washington (U.S. govt. Printing Office), 437-448.

Cotillon, P., 1983: Nouvelles méthodes d'appréciation du taux de sédimentation dans les séries pélagiques alternantes. Appplication aux corrélations stratigraphiques de haute précision. Comptes Rendus de l'Académie des Sciences, Paris, 296, 849-854.

Cotillon, P., Ferry, S., Gaillard, C., Jautée, E., Latreille, G. \& Rio, M., 1980: Fluctuation des paramètres du milieu marin dans le domaine vocontien (France S-E) au Crétacé inférieur: mise en évidence par l'étude des formations marno-calcaires alternantes. Bulletin de la Société géologique de France, Paris, 7, tome XXII, no. 5, 735-744.

Cotillon, P. \& Rio, M. (in press): Cyclic sedimentation in the Cretaceous of DSDP Sites 535 and 540 (Gulf of Mexico), 534 (Central Atlantic) and in the Vocontian Basin (France). Init. Repts. DSDP, 77: Washington (U.S. govt. Printing Office).

Croll, J. 1964: On the physical cause of the change of climate during geological epochs. Philos. Mag., 28, 121-137.

Darmedru, C., Cotillon, P. \& Rio, M., 1982: Rhythmes climatiques et biologiques en milieu marin pélagique. Leurs relations dans les dépôts crétacés alternants du bassin vocontien (S-E France). Bulletin de la Société géologique de France, Paris, 7, 24, 3, 627-640.

Debrabant, P., Chamley, H. \& Foulon, J. (in press): Paléoenvironmental implications of mineralogical and geochemical data in Western Florida Straits (leg 77 DSDP). Init. Repts. DSDP, 77: Washington (U.S. govt. Printing Office). 
Denis-Clocchiatti, M. 1982: Sédimentation carbonatée et paléoenvironnement dans l'Océan Indien au Cénozoique. Mém. Soc. Géol. Fr., Paris, Nouv. Série, LX, 1981, 143, 92 p., 74 fig., 28 tabl.

Dean, W. E., Gardner, J. V. \& Cepek, P. 1981: Tertiary carbonate dissolution cycles on the Sierra Leone Rise, Eastern Equatorial Atlantic Ocean. Marine Geology, 39, 81-101.

Ferry, S. \& Schaaf, A. 1981: The early Cretaceous environment at Deep Sea Drilling Project Site 463 (mid-Pacific mountains) with reference to the Vocontian trough (French subalpine ranges). In: Thiede J., Vallier T. L. et al., Init. Repts. DSDP, 62: Washington (U.S. Govt. Printing Office), $669-682$.

Fischer, A. G. 1980: Gilbert bedding rhythms and geochronology. Geol. Soc. of America, Spec. Paper, 183, 93-104.

Hays, J. D., Imbrie, J. \& Shackleton, N. J. 1976: Variatións in the Earth's Orbit: Pacemaker of the Ice Ages, Science, 194, 4270, 1121-1132.

Imbrie, J. 1982: Astronomical theory of the Pleistocene ice ages: a brief historical review. Icarus, 50, 2/3, 408-422.

Kaufmann, E. G. 1982: Ecology and Depositional Environments of chalk-marl and limestone-shale rythms in the Cretaceous of North America (Abstract). In: Cyclic and Event Stratification, Einsele G. and Seilacher A. (eds.), Spring. Verl., 97.

Kennedy, W. J. \& Odin, G. S. 1982: The Jurassic and Cretaceous time scale in 1981. In: Numerical dating in Stratigraphy, Odin (ed.), 556-592.

Kerr, R. A. 1981: Milankovitch climate cycles: old and unsteady. Science, 213, 4, 1095-1096.

McCave, I. N. 1979: Depositional features of organic carbonrich black and green mudstones at DSDP sites 387, western north Atlantic. In: Tucholke, B. D., Vogt, P. R., et al., Init. Repts. DSDP, 43: Washington (U.S. govt. printing Office), 441-416.
Michel, D. 1981: Les cycles astronomiques dans l'interprétation des rythmes des calcaires noduleux et lydjennes du Dévono-dinantien du Mont-Peyroux (Montagne Noire). $9 e$ réunion annuelle des Sc. de la Terre, Paris, Société Géologique de France (éd.), 440 (abstract of comm.).

Milankovitch, M. 1930: Mathematische Klimalehre und Astronomishe Theorie der Klimaschwankungen. In: Koppen, W. \& Geiger, R. (eds.), Handbuch der Klimatologie, $1, A, 176$

Milankovitch, M. 1941: Kanon der Erdbestrahlung und seine Anwendung auf das Eiszeitproblem. Ed. Spec. Acad. Roy. Serbe, Belgrade, 133, 633 pp., English transl., U.S. Dept. Commerc.

Moore, T. C., Pisias, N. G. \& Dunn, D. A. 1982: Carbonate time series of the Quaternary and late Miocene sediments in the Pacific Ocean: a spectral comparison. Marine Geology, 46, 217-233.

Pisias, N. G., 1976: Late Quaternary sediments of Panama basin: sedimentation rates, periodicities and controls of carbonate and opal accumulation. Geol. Soc. Amer., mem. $145,375-388$.

Schwarzacher, W. \& Fischer, A. G. 1982: Limestone-shale bedding and perturbation of the Earth's orbit. In Cyclic and Event Stratification, Einsele, G. \& Seilacher, A., (eds.), Springer, 72-95.

Thieuloy, J. P. 1977: Les ammonites boréales des formations néocomiennes du Sud-Est francais (Province subméditerranéenne). Géobios, Lyon, 10, 3, 395-461.

Vincent, E. 1981: Neogene carbonate stratigraphy of Hess Rise (central North Pacific) and paleogeographic implications. In Thiede, J., Vallier, T. L. et al., Init. Rpts. DSDP, 62: Washington (U.S. govt. Printing Office), 571-606. 